Graduate Institute of

International Studies I Geneva

Economics

HEI Working Paper No: 09/2004

\title{
What does the evidence tell us about fragmentation and outsourcing
}

\author{
Ronald Jones \\ University of Rochester \\ Henryk Kierzkowski \\ Graduate Institute of International Studies \\ Chen Lurong \\ Graduate Institute of International Studies
}

(C) The Authors.

All rights reserved. No part of this paper may be reproduced without the permission of the authors. 


\title{
What Does Evidence Tell Us About Fragmentation and Outsourcing?
}

\author{
Ronald Jones $^{*}$, Henryk Kierzkowski ${ }^{* *}$ and Chen Lurong ${ }^{* * *}$
}

Prepared for a Special Issue of International Review of Economics and Finance

October, 2004

\footnotetext{
${ }^{*}$ University of Rochester, Rochester, USA

** Graduate Institute of International Studies, Geneva, Switzerland

*** Graduate Institute of International Studies, Geneva, Switzerland
} 


\section{Introduction}

About thirty years ago international trade economists uncovered a phenomenon that had increasingly been permeating the international exchange of goods. Thanks to the outstanding work of Herbert Grubel and Peter Lloyd, overwhelming empirical evidence has been produced to demonstrate that a large part of international trade consists of flows of goods within the same industries. ${ }^{1}$ Two other stylized facts have emerged as well: First, the importance of intra-industry trade, as the new phenomenon came to be known, increased over time. Second, intra-industry exchanges have been particularly intensive between developed countries with similar per capita incomes and comparable factor endowments.

New facts demanded new theory. Although Grubel and Lloyd offered some penetrating suggestions as to what could account for this novel type of trade, more detailed theory emerged. A fresh chapter in the theory of international trade opened, with increasing returns to scale and monopolistic competition gaining a permanent place.

New problems have now come to the attention of policy makers and fresh events have captured the imagination of theorists. During the last decade or so, yet another form of international exchange has gained in importance - international outsourcing. Trade in parts and components, in middle products or in fragments of final goods (many names have been coined in this respect) has exhibited a dynamism exceeding that of trade in final goods. This paper focuses on trade in parts and components that result from the international fragmentation of production, a type of trade increasingly paramount in advanced stages of globalization. It occurs with the death of distance, to borrow the title of a remarkable book dealing with many aspects of globalization. ${ }^{2}$ Such trade expanded as the world economy achieved its most liberal state since WWII, and has grown impressively with recent enormous improvements in telecommunications, globalization of finances and reductions of entry costs in many sectors worldwide.

Section 2 of the paper reviews the existing evidence supporting the claim that trade in fragments and in middle products is today what intra-industry trade was in the last several

\footnotetext{
${ }^{1}$ The now classic reference is Grubel, H. and P. Lloyd (1975). The literature that has followed is too vast to be even listed. However, an assessment of the Grubel-Lloyd contribution from a perspective of 30 years, with many key references, can be found in P. Lloyd and H-H Lee (2002).

2 The reader is refered to F. Cairncross (1997).
} 
decades of the 20th century, with an important difference: Trade in middle products opens up an important role for developing countries.

After presenting the basic facts regarding international outsourcing, we propose, in Section 3 , to review a theory of fragmentation in production that is capable of explaining the reasons for the new phenomenon. This analytical framework, developed over the period of the last decade and a half, stresses the fact that the process of production need not be confined by the boundaries of a region within a country or, indeed, by national boundaries. The framework stresses the essential role of a wide range of services required to support and sustain fragmented production technologies. Technological progress, domestic liberalization and international negotiations all result in lowered prices of service links that encourage increased international fragmentation of production.

The theory of international fragmentation of production and outsourcing offers a number of testable hypotheses: It predicts that income growth will lead to more fragmentation and more trade in parts and components. Equally important, it asserts that lower prices of service links will work in the same direction. We put these predictions to a series of tests in Section 4. The empirical results allow a comparison with a prediction commonly made by the new economic geography to the effect that economic growth leads to agglomeration. We find this conclusion to be inconsistent at the international level with the data. The paper ends with concluding remarks.

\section{The Emergence and Growth of Trade in Parts and Components}

International fragmentation of production and the resulting trade in parts and components were already present in the early 1960s. The main driver of this process was the US economy adjusting to structural changes and attempting to remain competitive vis-à-vis Western Europe and Japan. Geography, costs and history all combined to select efficient sub-suppliers of US firms in Canada and Latin America. In analyzing the new phenomenon, the initial attention of trade theorists was concentrated on individual cases of outsourcing.

In an early World Bank study, David Morawetz (1981) provided an answer to the question Why are the Emperor's New Clothes not made in Colombia?. In responding to this query, he 
also identified the factors behind Colombia's initial success: Abundance of cheap labor with sufficient skills, relatively low costs of transportation, communications access and location in similar time zones all helped to launch and coordinate a new form of international production sharing. ${ }^{3}$ Unfortunately, macroeconomic instability, political tensions, trade union upheavals and exchange depreciations and uncertainty led American producers to switch to subsuppliers located in East Asia. After being a regional phenomenon, outsourcing went global. Notwithstanding, other Central and Latin American countries moved in to seize the new opportunity. Mexico is a case in point.

Unlike intra-industry trade, which favored exchanges among developed economies, outsourcing is good news for developing countries, at least for some of them. ${ }^{4}$ If they could not supply competitively a whole product, they could as a minimum capture production of certain segments and components. ${ }^{5}$ Heckscher-Ohlin and Ricardian trade models could readily be used to spell out details of a new and finer division of labor. However, the experience of a country like Colombia showed that comparative advantage could easily be lost to far-away competitors. Another outstanding example of regional outsourcing is found in the Canada-United States Automotive Products Agreement of 1965. The significant reduction in trade barriers led to a great expansion of trade in auto parts. ${ }^{6}$

The advantages of international fragmentation in the textile, clothing and automobile industries spread to other production sectors. And what was good for the United States could also be advantageous for other countries. Outsourcing soon characterized trade around the globe. It spread to countries in Eastern Europe even before they abandoned planning and switched to becoming market economies. IKEA established production facilities in Poland in the 1970 's. ${ }^{7}$

\footnotetext{
${ }^{3}$ US offshore assembly scheme (807) contributed to the development of international production sharing especially in the clothing industry.

${ }^{4}$ Of course, complete disagreement with this statement can be found in some of the current arguments levied against globalization.

${ }^{5}$ This theme was developed further in Jones and Kierzkowski (1990).

${ }^{6}$ Looking at the aggregate US trade since 1962, Kei-Mu Yi (2003) finds that over 50 percent of the trade expansion can be explained by increased vertical specialization brought about by tariff reductions. Tariff cuts even of modest magnitudes produce large non-linear responses of trade in a model with stages of production. ${ }^{7}$ It may be ironic to recall that many pundits argued at the time that Eastern Europe was not only a low-wage region but also that trade unions there were docile and would not strike.
} 
It is generally thought that international corporations were most responsible for these initial moves towards international outsourcing. The main argument was that only a large scale of operation and an international outlook could give a company the necessary knowledge to see outsourcing opportunities and sufficient resources to take advantage of them. Helleiner (1981) provided some evidence in support of a rapid growth of intra-firm trade carried out by large multinationals. Even today the role of large international firms is often emphasized or even overstated. However, as globalization has leveled the field of competition, and liberalization has torn down barriers to entry, the alleged advantage of large international firms has somewhat diminished. ${ }^{8}$

Countries in East Asia have been important in international fragmentation of production and outsourcing. We have already alluded to the fact that in spite of geographic proximity, U.S. producers found Latin America somewhat lacking in economic and political stability and they soon voted with their feet by moving to East Asian locales. One striking feature of Asian trade in parts and components has been its selective character. Exports of components of office and adding machinery and of telecommunications equipment represented in the late 1990s just over half of total regional exports of parts and components. ${ }^{9}$ Adding to these two items parts of motor vehicles and accessories increases the concentration ratio to almost two thirds of total export of parts and components.

East Asia does much more than supply US and European firms with middle products. Regional production sharing networks interact and support one another, leading to an expansion in trade in parts and components within East Asia as well. ${ }^{10} \mathrm{Ng}$ and Yeats have established that: Asian global exports of components increased more than fivefold over the 1984-96 period, while total exports of all goods rose by a factor of approximately 3. However, the value of component exports to the region grew by a factor of about 10 , which was roughly double that for all regional trade. ${ }^{11}$ These trends in intra- and extra-regional East Asian trade in parts and components suggest major forces operating in that part of the world economy.

\footnotetext{
${ }^{8}$ See the paper by Fukunari Kimura and Mitsuyo Ando in this issue showing that in the case of Japanese multinationals there has been a shift from intra-firm to arm's-length trade in fragmented goods.

${ }^{9}$ This statistic is contained in Ng and Yeats (2001). The group of countries classified as East Asia consists of Japan, Hong Kong, Republic of Korea, China, Singapore, Taiwan, Malaysia, Thailand, Indonesia and the Philippines.

${ }^{10}$ This happens even though there is no equivalent of a NAFTA or EU in East Asia.

${ }^{11}$ Quoted from Ng and Yeats (2001), p. 69.
} 
The Japanese economy appears to be the major driver of intra-regional trade. ${ }^{12}$ Japan, with approximately a $40 \%$ share of the market, is both exporter and importer of parts and components. But it is the former role that seems to be more important as restructuring of Japanese industries turned many countries of the region into assemblers of Japanese products.

The process of international fragmentation of production is clearly a dynamic phenomenon. Nowhere can it be seen better than in East Asia. Comparative advantage shifts constantly from one place to another and international firms go to a great deal of trouble to spot even minute cost differences. Asian firms engaging in international production sharing reach just as high production standards as those met by American or European firms. Taiwan and Singapore are excellent examples of upgrading and moving into more human capitalintensive stages of production. Whereas Taiwan began as a supplier of simple labor-intensive parts for computers, it is now the top computer designer in the world. This type of opportunity has not been lost on Korea and other East Asian countries.

While international fragmentation of production and outsourcing have received less attention in Europe than in North America, European multinationals have been practicing it for several decades. Those multinational firms sometimes even came from small countries e.g. Sweden with IKEA and Eriksson; and Switzerland with Nestlé and several other pharmaceutical firms.

Shifting output fragments to Asia in order to increase competitiveness of European products in international markets has been practiced by large, medium-size and small firms as a part of their restructuring activities. And the use of outsourcing was not limited to manufacturing sectors; service activities as well have utilized fragmentation and international outsourcing. Already in the late 1980's Swissair had moved a lot of its accounting tasks to India; the City of London also turned to that India for computer maintenance services. ${ }^{13}$

\footnotetext{
${ }^{12}$ While Japan's position is still dominant, the importance of China is rapidly increasing. One should also keep in mind that Hong Kong (now China) was behind many of the regional arrangements. As its economy has become service oriented, the Hong Kong business community provides many essential service links. Knowledge of local conditions, excellent connections with business communities in North America and Europe, a mastering of modern management techniques and the ability to put together financing required for international production networks constitute only some of its assets. For more on production networks in East Asia see Chen and Kierzkowski (2001).

${ }^{13}$ In the case of computer maintenance service distance can spur rather than hinder closer cooperation by making positive use of differences in time zones.
} 
A new dimension to regional production sharing in Europe has been added by the economic transformation of Eastern Europe. Integration with the world economy and especially with the European Union has been a key driver of reforms undertaken by transition economies. This has meant more than just a lowering of trade barriers. Also involved are geographic realignments of trade patterns and the development of new products for exports to much more demanding markets. In a relatively short period of time transition economies have intensified intra-industry trade with Western Europe. They have also developed production sharing arrangements with numerous European Union firms ${ }^{14}$. According to Kaminski and Ng (2003) all ten new members of the EU engage in trade in parts and components. Particular progress has been achieved in furniture and automobiles. Egger and Egger (2003) show that the lowering of trade barriers and low wages in Eastern Europe have persuaded countries such as Austria to reallocate labor-intensive stages of production to that region.

Empirical studies of outsourcing as a worldwide phenomenon have been hampered by a lack of systematic statistics. The SITC classification system simply did not distinguish between trade in final goods and trade in parts and components. This unfortunate situation has begun to change only recently as countries started to apply the SITC Revision 2 system, with greatly increased numbers of categories containing parts and components within individual product groups. ${ }^{15}$ We are still far from a satisfactory situation in this respect because not all the countries made a switch to the SITC Revision 2 system. As well, the degree of differentiation of parts and components varies across commodity groups.

Although incomplete, statistics on trade in parts and components that cover a relatively short period of time can reveal a number of interesting trends. The question How big is global production sharing has been convincingly answered by Yeats: it is very big indeed. ${ }^{16}$

Figure 1 shows the growth of trade in parts and components during the period 1990 - 2000.17 For the world as a whole the new type of trade grew from $\$ 355$ billion to $\$ 846$ billion which gives an average rate of growth of $9.1 \%$ per year. By comparison, total world trade grew at $6.5 \%$ per year on average, while the world GDP expanded by 3,7\% during the same period. It

\footnotetext{
${ }^{14}$ For a more complete analysis of fragmentation of production involving Eastern Europe see Kierzkowski (2001) and Graziani (2001).

${ }^{15}$ One should point to the fundamental work carried on by Francis Ng and Alexander Yeats of the World Bank in extracting, processing and analysing statistics related to international trade in parts and components.

${ }^{16}$ See Yeats (2001).

${ }^{17}$ We are very grateful to Francis Ng for making these date vailable to us. The data will also be used in section 4 of this paper.
} 
seems virtually certain that trade in parts and components grew faster than intra-industry trade. It is clearly a new phenomenon that merits close scrutiny.

Figure 1. Global income and trade, 1990-2000

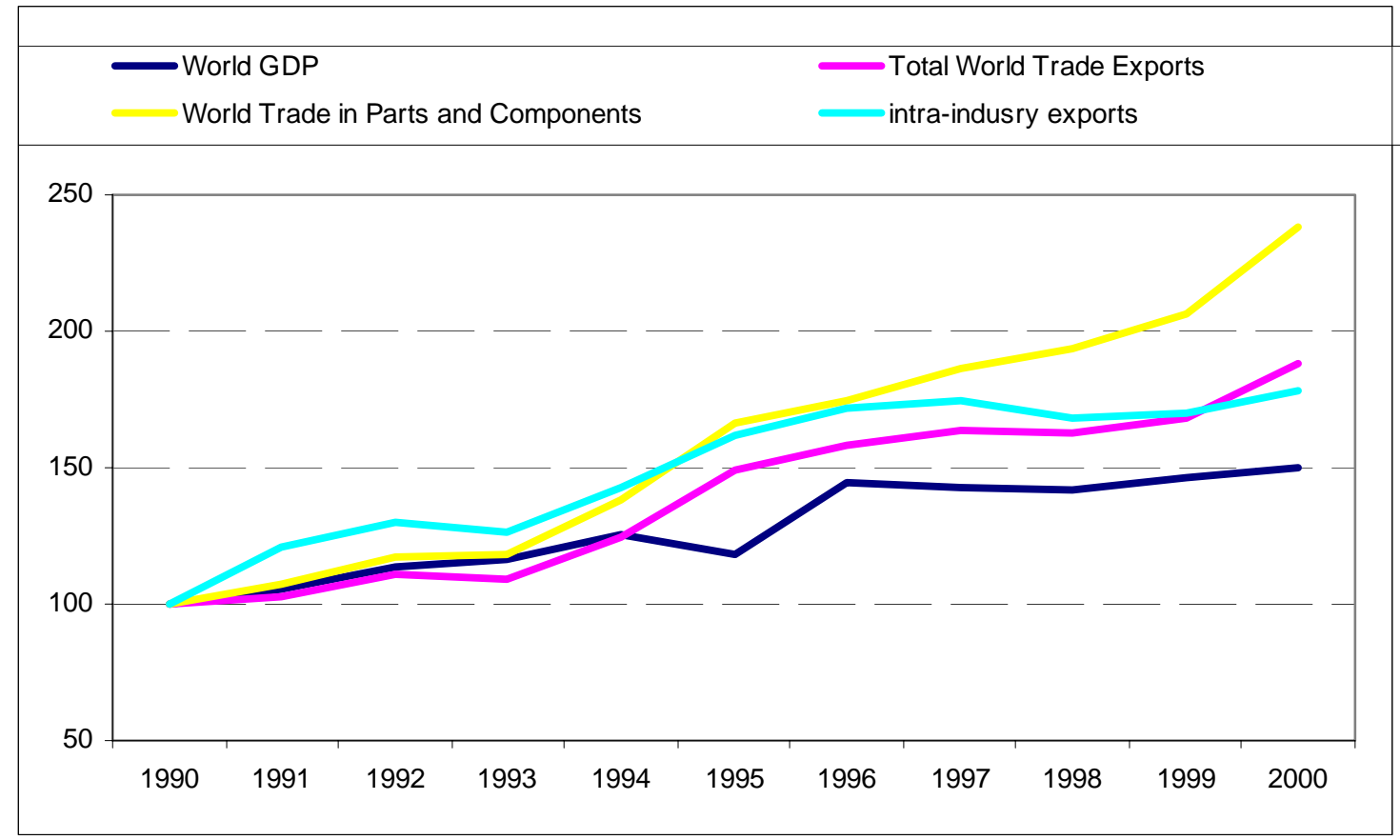

Data source:

1. GDP form World Develop Indicator, 2002, World Bank

2. Trade data comes from Ng and Yeats (2001)

3. Intra-industry exports data is calculated from Industrial Demand-Supply Balance Database, 2004, UNIDO

Notes: Year 1990 is the base year.

We are also able to shed some light on intra and extra-regional growth of trade in parts and components for NAFTA, the EU 15 and East Asia. ${ }^{18}$ The comparison of regions shown in Figure 2 seems to be most interesting. First of all, the EU 15 has been the most important player in the new game throughout the entire period. This is true for both intra and extraregional trade of the European Union. East Asia is now emerging as the second most important region with regard to trade in parts and components.

A comparison of intra- versus extra-regional rates of growth shows that the European Union is becoming more outward oriented when it comes to trade in middle products. External trade expanded by an average annual rate of $8.8 \%$ while internal trade grew at $5.2 \%$.

\footnotetext{
${ }^{18}$ East Asia is defined here as consisiting of Japan, Brunei, Darussalam, Cambodia, Hong Kong (China), Indonesia, Kore (Republic of) Lao P.D.R., Malaysia, Mongolia, Philippines, Taiwan, China, Thailand and Viet Nam.
} 
It would seem that the name European fortress is misplaced in this case. In the years to come the picture may change substantially due to the latest enlargement. In the case of East Asia and NAFTA intra-regional trade grew more rapidly than extra-regional exchanges. For East Asia the corresponding average rates are $13.6 \%$ and $9.3 \%$, and for NAFTA $11.5 \%$ and $7.6 \%$. It may well be that the European Union will lose its predominant position with regard to trade in parts and components. East Asia is most likely to take a leading role in this regard. ${ }^{19}$

Figure 2. Trade in Parts and Components by Regions (million of US dollars)

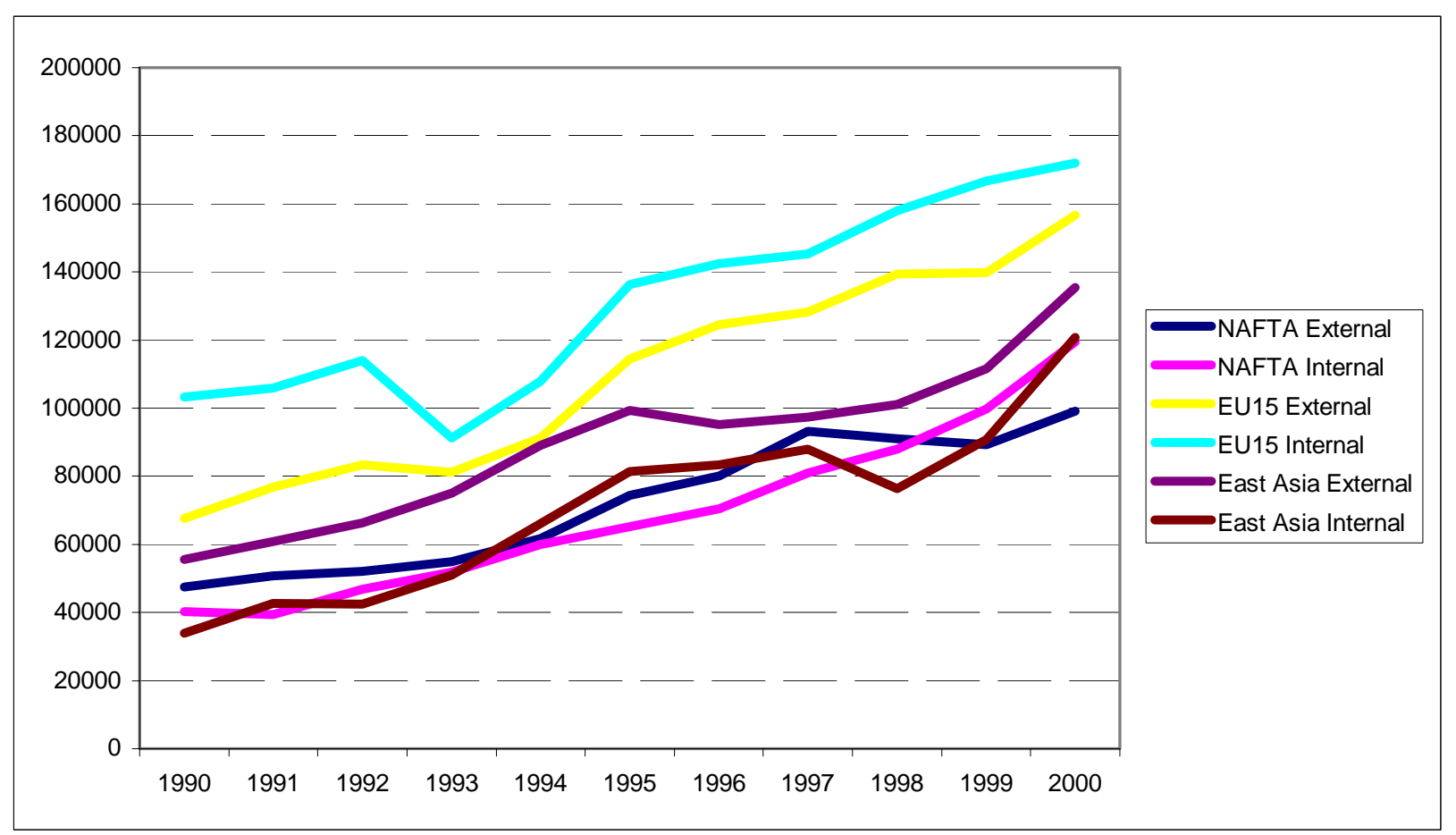

Data source: Ng and Yeats (2003)

\section{The Theory of Fragmentation in Production and Outsourcing}

Before turning to our empirical results it may prove useful to review several of the principal features underlying the rise in international outsourcing of production and services. As sketched out in Jones and Kierzkowski (1990) and subsequent work, the existence of increasing returns is crucial in the understanding of the outsourcing phenomenon. Adam

\footnotetext{
${ }^{19}$ If the analysis was broaden to include India then the Asian continent can soon become a vast bastion of production sharing for regional and worldwide destinations.
} 
Smith emphasized the division of labor, whereby as scale increases each worker can become more specialized in particular tasks. The extent of the market, i.e. scale of production, would determine the lengths to which such division of labor can proceed. This idea is generalized by considering that at low levels of output resources are combined in an integrated production block. Such a process can be vertically fragmented into two or more production blocks that could each be produced in a separate locale. The attraction for such a fragmentation could be found in different requirements for labor skills, with one region (or country) containing labor of skills more appropriate to one fragment and another region populated by labor relatively more productive in the other fragment. (This would build upon the Ricardian view of differing relative productivities of labor). Alternatively, it might be the case that different fragments require inputs in different proportions, and relative factor supplies and prices could differ from region to region, suggesting that the more labor-intensive fragment be located in the more labor-abundant region, and the more capital-intensive fragment in another region. (This reasoning follows Heckscher-Ohlin lines for the basis for trade). However, such fragmentation is not costless. Separate production blocks need to be coordinated, which involves incurring costs of transportation, communication, insurance and other connecting service links. We postulate that such service link activities usually exhibit strong increasing returns to scale. For example, the costs of communication to allow coordinated shipments of two production blocks would not be much different for outputs of one thousand units and those of ten thousand units. As a consequence there is a natural trade-off between costs of service links and costs of production blocks. More fragmented production, by taking advantage of dissimilarities of input requirements in production blocks and differences in input prices among regions, can exhibit lower aggregate costs for these blocks, but higher costs of connective service links. Greater levels of outputs encourage greater degrees of fragmentation.

Figure 3 portrays the manner in which fragmentation of production processes results in increasing returns to scale. ${ }^{20}$ Ray 1 from the origin describes how production costs would rise relative to output if all production took place in a single production block subject to constant returns to scale. Alternative techniques, involving a fragmentation of the production process, are also available. For example, line 2 suggests that breaking the process up into two production blocks, each better suited to a region in which, say, factor prices are relatively low

\footnotetext{
${ }^{20}$ This diagram appears in Jones and Kierzkowski (2004).
} 
for the factor intensively used in that block, can result in a lowering of marginal costs of production (the slope of line 2). However, these blocks must be coordinated by service links which, in Figure 3, are captured by distance 0A. That is, our assumption that increasing returns are a feature of service link activities is highlighted in Figure 1 by assuming costs of coordinating services are completely of the fixed cost variety. In similar fashion, lines 3 and 4, progressively flatter, reveal how further degrees of fragmentation, with a better fit of fragments to regions, can lower total marginal costs of production, but at the expense of higher service link requirements. Indeed, costs of amount 0C for line 4 might suggest that some fragments are being outsourced to different countries, with a corresponding lowering of marginal costs but increases in the costs of service links. What Figure 3 reveals by the heavy broken cost line is that optimal behavior involves a selection of techniques that minimize total costs of production, and this entails that greater degrees of fragmentation, leading eventually to international outsourcing, are a natural consequence of increases in output and incomes.

Figure 3. Costs and Fragmented Production

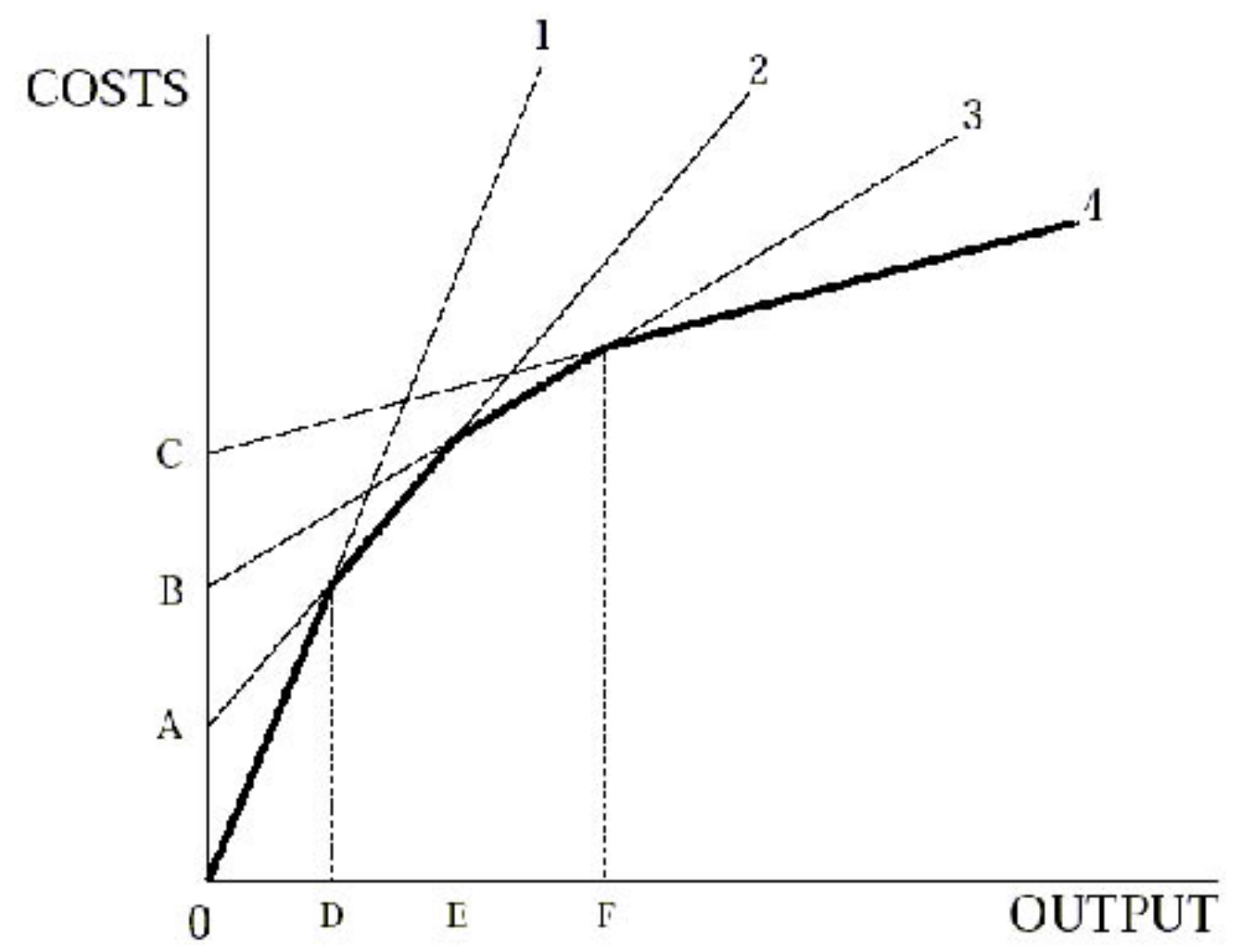


Such a relationship is one of the connections to be tested in the next section. In addition, as previously noted, recent technological improvements in service link activities, as well as reductions in service regulations and a lowering of international barriers to services trade, have all conspired to reduce the costs of services. As a consequence, in Figure 3 these changes would result in a lowering of the vertical intercepts of lines 2, 3, and 4, suggesting that even for a given level of output an increase in the degree of fragmentation and outsourcing may well be observed. These are the primary relationships for which we seek evidence. To the extent that such outsourcing activity is promoted, the new economic geography argument that increasing returns helps to promote increasing agglomeration of economic activity is contradicted, at least at the international level, by the evidence. ${ }^{21}$

\section{Empirical Results}

The purpose of this section is to test the validity of the fragmentation-outsourcing framework against empirical data. Given the limited data base there is no hope of estimating a full-scale model that would include behavioral relationships, identities, etc. And in fact, proceeding directly to reduced form equations may even be desirable. This is so because the fragmentation framework does not depend on a particular market structure. Its main massage carries through under perfect competition as well as in a monopolistic market setting. ${ }^{22}$ Estimation of a structural model would have to spell out in detail the behavior of a firm and place it within a market.

What, then, is the main message of the fragmentation framework? Fortunately it can be stated clearly and unambiguously:

1. The optimal degree of fragmentation depends on the size of the market. Economic growth encourages fragmentation and trade in parts and components.

2. Lowering of service links costs promotes fragmentation and outsourcing of output.

\footnotetext{
${ }^{21}$ This line of reasoning is spelled out in more detail in Jones and Kierzkowski (2004).

${ }^{22}$ We have argued on a number of occasions that in developing the fragmentation framework one would be well advised to keep an open mind regarding the organization of firms and industries. Perfect competition seems a good staring point, especially because it allows the theorist to make use of the Ricardian and Heckscher-Ohlin models. But, of course, one could take an alternative route. Empirical evidence on the role of intra-firm trade and increasing returns to scale in manufacturing should perhaps guide research strategy. Another and even more intriguing question is how to model service sectors where increasing returns to scale seem more of a rule.
} 
It is an open question how best to measure the size of the market. One could argue that the scale of an industry, or even of an individual firm, is the relevant variable in considering the optimal degree of fragmentation. On the other hand, if different parts or components such as computer chips, monitors or even bearing balls are standardized and used across a range of industries, a more aggregate measure of output is required. ${ }^{23}$

The whole problem could be approached from the perspective of final demand. After all, the size of output is significantly determined by demand - local, regional or even global. Thus as the regions and the global economy grow richer, the scale of output of industries conducive to fragmentation and the degree of fragmentation should increase.

An appropriate service variable is also hard to come by. In the Jones-Kierzkowski framework a composite service linking production blocs is used in recognition of the fact that transportation, banking, insurance, $\mathrm{R} \& \mathrm{D}$ and telecommunication activities are indispensable in any sector in the modern world. It can be argued that a whole array of services should be used as explanatory variables. Alternatively, all of them should be combined and served as a synthetic measure. As a first cut, however, we propose to use business telephone charges as an explanatory variable that should play a major role in explaining day-to-day activities of firms regardless of the industry. This variable captures voice and Internet communications between producers.

Given the above discussion, the following equation is proposed for estimation:

\section{(1) Log (Trade in $\left.P \& C_{\text {region }}\right)=C+\delta_{1} \log \left(G D P_{\text {region }}\right)$ \\ $+\delta_{2} \log \left(\right.$ Average Business Connection Charges ${ }_{\text {region }}$ )}

Equation (1) has been estimated for the world as a whole and also for intra and extra-regional trade of NAFTA, EU 15 and East Asia. The data used in estimation have been discussed in connection with Figures 1 and 2. The results are reported in Table 1.

\footnotetext{
${ }^{23}$ Jones and Kierzkowski discuss horizontal aspects of vertical fragmentation of production in Cheng and Kierzkowski (2001).
} 
Table 1. Regressions of Regional Trade in Parts and Components on Regional GDP and Regional Average Business Connection Charges

(Logarithmic Specification)

\begin{tabular}{|c|c|c|c|c|c|c|c|}
\hline & World & $\begin{array}{l}\text { East Asia } \\
\text { External }\end{array}$ & $\begin{array}{c}\text { East Asia } \\
\text { Internal }\end{array}$ & $\begin{array}{c}\text { EU15 } \\
\text { External }\end{array}$ & $\begin{array}{c}\text { EU15 } \\
\text { Internal }\end{array}$ & $\begin{array}{l}\text { NAFTA } \\
\text { External }\end{array}$ & $\begin{array}{l}\text { NAFTA } \\
\text { Internal }\end{array}$ \\
\hline C & $\begin{array}{c}-14.13 \\
1.79\end{array}$ & $\begin{array}{l}-9.18 \\
-6.24 * * *\end{array}$ & $\begin{array}{c}-19.24 \\
6.41^{* * *}\end{array}$ & $\begin{array}{l}-15.27 \\
3.96 * * *\end{array}$ & $\begin{array}{l}-7.70 \\
-1.84^{*}\end{array}$ & $\begin{array}{c}-5.31 \\
-0.67\end{array}$ & $\begin{array}{l}-18.91 \\
-4.86^{* * *}\end{array}$ \\
\hline$\delta_{1}$ & $\begin{array}{c}1.64 \\
3.94 * * *\end{array}$ & $\begin{array}{l}1.49 \\
15.3^{* * *}\end{array}$ & $\begin{array}{c}2.14 \\
10.77^{* * *}\end{array}$ & $\begin{array}{l}1.85 \\
7.96 * * *\end{array}$ & $\begin{array}{l}1.35 \\
5.34 * * *\end{array}$ & $\begin{array}{c}1.07 \\
4.64 * * *\end{array}$ & $\begin{array}{c}2.04 \\
17.96^{* * *}\end{array}$ \\
\hline $\boldsymbol{\delta}_{2}$ & $\begin{array}{c}-0.14 \\
-0.79\end{array}$ & $\begin{array}{l}-0.55 \\
-6.32^{* * * *}\end{array}$ & $\begin{array}{l}-0.64 \\
-3.59 * *\end{array}$ & $\begin{array}{l}-0.50 \\
-7.40^{* * * *}\end{array}$ & $\begin{array}{l}-0.38 \\
-5.11^{* * * *}\end{array}$ & $\begin{array}{l}-2.61 \\
-2.48^{* *}\end{array}$ & $\begin{array}{c}-0.57 \\
-1.10 \\
\end{array}$ \\
\hline $\mathbf{R}^{2}$ & 0.89 & 0.97 & 0.94 & 0.96 & 0.92 & 0.96 & 0.99 \\
\hline DW & 2.09 & 2.06 & 1.40 & 2.01 & 1.58 & 1.73 & 2.20 \\
\hline
\end{tabular}

Notes:

1. $\quad * * *$ denotes statistically significant at $99 \%$; $* *$ denotes statistically significant at $95 \%$; and $*$ denotes statistically significant at $90 \%$

2. we use average business telephone connecting charge of USA to proxy the average level of NAFTA

. The income variable comes in strongly and the relationship between trade flows and income is positive. The income coefficients are significant at 99\% level in all cases. Trade flows seem to be very elastic with regard to income, a 10 percent growth of income leads to increases in trade in parts and components between 10 and 21\%. Growth of regional income especially encourages expansion of intra-regional trade in parts and components in the case of East Asia and NAFTA and strongly favors external trade in the case of the EU. This result may sound surprising since it means that EU trade in parts and components is more of a global phenomenon whereas NAFTA trade has a more regional character.

The results reported in Table 1 allow us to test the power of the fragmentation theory against the new economic geography. According to the first approach, disagglomeration is to be expected in the global economy when it becomes larger. The latter strand of literature conveys a message that agglomeration is the norm in the presence of increasing returns to scale in manufacturing when the scale of output increases. Clearly, the disagglomeration school carries the day. In every estimated equation the income coefficient has the correct sign, 
i.e. positive. This is good news for countries that want to break into the global trading system. Economies of scale will not disallow participation in the new international division of labor.

The second message carried by the fragmentation in production framework concerns services. The results reported above show that world business connection charges tend to come in as predicted by the theory. In five cases out of seven the coefficient is highly significant and it always has the right sign.

The strongest impact of the world business connections variable is in the case of NAFTA's external trade where a $10 \%$ decline in the price increases trade by $26.1 \%$. Will NAFTA emerge as the main source of intra-continental trade in parts and components? That depends on further growth of income compared to further reductions of service prices. Table 1 shows that a high rate of income growth strongly promotes external trade of the European Union. For NAFTA to overtake other regions in external trade in parts and components requires relatively rapid income growth in North America and further progress in bringing down world business connection charges.

While the empirical analysis reported here does not contradict the main conclusions of the fragmentation theory, a devil's advocate could argue that higher income and lower service prices should be promoting trade in general, not only trade in middle products. After all, if it becomes cheaper to arrange a production sharing deal between Singapore and the United States then it is also cheaper to sell the final product between the two countries. We thus turn to estimation of an equation in which the endogenous variable is the relative share of trade in parts and components. The logic of fragmentation theory says that the income and service variables will have a stronger impact on trade in parts and components than on trade in general. Positive income coefficients and negative service variable coefficients are therefore expected. This is indeed the case as shown by Table 2 .

(2) $\log \left(\frac{\text { Trade in P\&C }}{\text { Total Trade Exports }}\right)_{\text {region }}=\mathbf{C}+\zeta_{1} \log \left(\mathbf{G D P}_{\text {region }}\right)$

$+\zeta_{2} \log ($ Average Business Connection Charges region$)$ 
Table 2. Regressions of Relative Share of Trade in Parts and Components on Regional GDP and Regional Average Business Connection Charges

(Logarithmic Specification)

\begin{tabular}{|c|c|c|c|c|c|c|c|}
\hline & World & $\begin{array}{c}\text { East Asia } \\
\text { External }\end{array}$ & $\begin{array}{l}\text { East Asia } \\
\text { Internal }\end{array}$ & $\begin{array}{c}\text { EU15 } \\
\text { External }\end{array}$ & $\begin{array}{c}\text { EU15 } \\
\text { Internal }\end{array}$ & $\begin{array}{l}\text { NAFTA } \\
\text { External }\end{array}$ & $\begin{array}{l}\text { NAFTA } \\
\text { Internal }\end{array}$ \\
\hline C & $\begin{array}{c}-0.87 \\
-0.54\end{array}$ & $\begin{array}{l}-2.46 \\
-2.66 * *\end{array}$ & $\begin{array}{l}-4.59 \\
-3.84^{* * *}\end{array}$ & $\begin{array}{c}-3.72 \\
-1.55\end{array}$ & $\begin{array}{c}-0.72 \\
-0.43\end{array}$ & $\begin{array}{l}-5.85 \\
-8.40^{* * *}\end{array}$ & $\begin{array}{l}2.39 \\
2.86^{* *}\end{array}$ \\
\hline$\zeta_{1}$ & $\begin{array}{l}0.19 \\
1.91^{*}\end{array}$ & $\begin{array}{c}0.33 \\
5.78^{* * *}\end{array}$ & $\begin{array}{c}0.42 \\
5.71^{* * *}\end{array}$ & $\begin{array}{l}0.37 \\
2.44^{* *}\end{array}$ & $\begin{array}{c}0.18 \\
1.63\end{array}$ & $\begin{array}{c}0.45 \\
5.41^{* * *}\end{array}$ & $\begin{array}{c}0.12 \\
1.25\end{array}$ \\
\hline$\zeta_{2}$ & $\begin{array}{l}-0.13 \\
-3.05^{* *}\end{array}$ & $\begin{array}{c}-0.03 \\
-0.53\end{array}$ & $\begin{array}{l}-0.34 \\
-5.16^{* * *}\end{array}$ & $\begin{array}{l}-0.21 \\
-4.80^{* * *}\end{array}$ & $\begin{array}{l}-0.19 \\
-5.99 * * *\end{array}$ & $\begin{array}{c}-0.61 \\
-1.62\end{array}$ & $\begin{array}{c}0.57 \\
1.27\end{array}$ \\
\hline $\mathbf{R}^{2}$ & 0.90 & 0.81 & 0.85 & 0.86 & 0.88 & 0.96 & 0.17 \\
\hline DW & 1.40 & 1.34 & 2.47 & 1.43 & 1.73 & 1.68 & 1.36 \\
\hline
\end{tabular}

Notes:

1. $* * *$ denotes statistically significant at $99 \%$; $* *$ denotes statistically significant at $95 \%$; and $*$ denotes statistically significant at $90 \%$

2. we use average business telephone connecting charge of USA to proxy the average level of NAFTA

As can be verified, the main prediction of fragmentation theory with regard to the relative importance of trade in parts and components is not contradicted by the data. In all cases except the one concerning NAFTA's internal trade, a large part of the variation in the endogenous variable is explained, and the coefficients have the correct signs. While higher incomes and lower service prices promote trade in general, they favor particularly strongly trade in parts and components.

\section{Conclusions}

International outsourcing has become a symbol of globalization. The data clearly show the great increase in trade in parts and components. It surpasses the expansion of intra-industry trade which some observers have also seen as a key characteristic of the modern economy. The phenomenon merits a theoretical explanation and empirical testing, the subject of the present paper.

The theory of the fragmentation of vertically integrated production processes leading to international outsourcing can be readily applied to the problem at hand. The data do not 
contradict the main predictions of this theory. Actual trade flows suggest that disagglomeration seems to be more prevalent in the global economy than agglomeration. 


\section{References}

Arndt, S. and H. Kierzkowski, (eds.), 2001, in Fragmentation: new production and trade Patterns the world economy, (Oxford University Press, Oxford).

Cairncross, F., 1997, The death of distance, (Harvard Business School Press, Boston).

Cheng, L. and Henryk Kierzkowski, (eds.), 2001, Globalization of trade and production in South-East Asia, (Kluwer Academic Press, New York).

Egger, H and P. Egger, 2001, Outsourcing and skill- specific employment in a small country: Austria after the fall of the iron curtain, Oxford Economic Papers, 55, pp 625 - 643.

Graziani, G., 2001, International subcontracting in the textile and clothing industry, in Arndt, S. and H. Kierzkowski, (eds.), 2001.

Grubel, H. and P. Lloyd, 1995, Intra-industry trade, (Macmillan, London).

Helleiner, G., 1981, Intra-firm trade and the developing countries, (Palgrave Macmillan, London).

Jones, R. W. and H. Kierzkowski, 1990, "The role of services in production and international trade: A theoretical framework", in R. Jones and A. Krueger, The political economy of international trade: Festschrift in honor of Robert Baldwin, (Basil Blackwell, Oxford).

2001, "Globalization and consequences of international fragmentation”, in R. Dornbusch, G. Galvo and M. Obsfeld, (eds.), Money, capital mobility and trade: Festchrift in honor of Robert A. Mundell, (MIT Press, Cambridge, Massachusetts).

2003, "International trade and agglomeration: an

alternative framework", forthcoming in The Journal of Economics.

2003, "International fragmentation and the new economic geography,” forthcoming in North American Journal of Finance.

Kaminski, B, and F. Ng, 2001, Trade and production fragmentation: Central European economies in European Union networks of production and marketing, World Bank, Working Paper 2611, Washington, D.C.

P. Lloyd and H-H Lee, 2002, (eds.), Frontiers of research in intra-industry trade, (Macmillan, London).

Morawetz, D. 1981, Why the emperor's new clothes are not made in Colombia, (Oxford University Press, Oxford).

Ng, F. and A. Yeats, 2003, "Major trade trends in Asia - What are implications for regional cooperation and growth," The World Bank, World Bank Policy Research Working Paper 3084, June, Washington DC 
Yeats, A., 2001, How big is global production sharing? in Arndt, S. and $\mathrm{H}$. Kierzkowski, 2001.

Yi, K-M, 2003, Can vertical specialization explain the growth of world trade?, Journal of Political Economy, February, pp.52-102. 